\title{
Preserving the Knowledge of the Past Through Virtual Visits: From 3D Laser Scanning to Virtual Reality Visualisation at the Istanbul Çatalca İnceğiz Caves
}

\author{
Gürcan Büyüksalih ${ }^{1} \mathbb{D} \cdot$ Tuna Kan $^{1} \cdot$ Gözde Enç Özkan ${ }^{1} \cdot$ Müge Meriç ${ }^{1} \cdot$ Lale Isın $^{1} \cdot$ Thomas P. Kersten $^{2}$ (D)
}

Received: 12 September 2019 / Accepted: 13 January 2020 / Published online: 28 February 2020

(c) The Author(s) 2020, corrected publication 2021

\begin{abstract}
Cultural landscapes are those that are shaped through the combined forces of cultural and natural activity, typically over a long period that may reach back to historic and prehistoric times. Amongst these, the documenting, modelling and visualisation of cave landscapes have always been particularly important for scientific communities such as speleology. In the current state of the art, terrestrial laser scanning provides a level of documentation of objects whose accuracy cannot be achieved by conventional methods. In addition to the highly accurate metric and geometric information, visual information brings incredible richness to the presentation of data. Virtual reality (VR) allows individuals to immerse themselves within virtual environments to explore monuments and other cultural heritage sites up close. More and more, VR systems are available at lower prices and are not only limited to VR labs. In this paper, we present research on the generation of a virtual 3D model of the İnceğiz caves, located at the Çatalca district of Istanbul, Turkey, and its integration within the Unity 3D game engine. This project, carried out as a collaboration between BİMTAŞ, a company of the Greater Municipality of Istanbul, Turkey and the Photogrammetry \& Laser Scanning Lab of the HafenCity University Hamburg, Germany, aimed at developing an immersive and interactive VR visualisation of the cave for the HTC Vive Pro VR system. The entire workflow, from data acquisition to VR visualisation, is described here in detail with particular emphasis given to the 3D modelling of the cave and its integration within a VR environment.
\end{abstract}

Keywords 3D $\cdot$ Cave $\cdot$ HTC Vive Pro $\cdot$ Modelling $\cdot$ Digital reconstruction $\cdot$ Virtual reality

Thomas P. Kersten

Thomas.Kersten@hcu-hamburg.de

Gürcan Büyüksalih

gbuyuksalih@yahoo.com

Tuna Kan

tuna.kan@bimtas.istanbul

Gözde Enç Özkan

gozde.encozkan@bimtas.istanbul

Müge Meriç

muge.meric@bimtas.istanbul

Lale Isin

laleisin@bimtas.istanbul

1 Boğaziçi İnşaat Müşavirlik A.Ş. (BİMTAŞ), Evliya Celebi

Mah. Mesrutiyet Cad. Eski TÜYAP Binasi No. 50, 34430

Tepebaşı - Beyoğlu, Istanbul, Turkey

2 Photogrammetry \& Laser Scanning Lab, HafenCity University Hamburg, Überseeallee 16, 20457 Hamburg,

Germany 


\section{Zusammenfassung}

Die Bewahrung des Wissens über die Vergangenheit durch virtuelle Besuche: Vom 3D-Laserscanning bis zur Visualisierung der Çatalca İnceğiz. Höhlen bei Istanbul durch Virtual Reality. Kulturlandschaften werden durch vereinte Kräfte kultureller und natürlicher Aktivitäten geformt. Sie haben oft eine lange Geschichte, die bis in historische und prähistorische Zeiten zurückreicht. Zu den Kulturlandschaften gehörten schon immer auch Höhlenlandschaften, die für wissenschaftliche Fachgebiete wie Speläologie (Höhlenforschung) von besonderer Bedeutung sind, und daher dokumentiert, modelliert und visualisiert werden. Derzeit ist das terrestrische Laserscanning dafür Stand der Technik, da es eine sehr gute geometrische Dokumentation mit einer bislang als unerreichbar geltenden Genauigkeit erlaubt. Zusätzlich zu den hochpräzisen metrischen und geometrischen Informationen unterstützt die visuelle Information (Farbe) eine hochwertige Visualisierung. Die virtuelle Realität (VR) ermöglicht es dem Einzelnen, in die virtuelle Welt einzutauchen und Umgebungen von Denkmälern und andere Stätten des Kulturerbes aus nächster Nähe zu erkunden. Immer mehr VR-Systeme sind heute für wenig Geld verfügbar und daher nicht mehr nur auf VR-Labore beschränkt. In diesem Artikel stellen wir Untersuchungen zur Erstellung eines virtuellen 3D-Modells der Höhlen von İnceğiz im Stadtteil Çatalca in Istanbul, Türkei, und dessen Integration in die Unity 3D-SpieleEngine vor. Dieses Projekt wurde in Zusammenarbeit mit BIMTAŞ, einem Unternehmen der großen Stadtverwaltung von Istanbul, und dem Labor für Photogrammetrie und Laserscanning der HafenCity Universität Hamburg mit dem Ziel durchgeführt, eine immersive und interaktive VR-Visualisierung der Höhle für das VR-System HTC Vive Pro zu entwickeln. Der gesamte Datenfluss von der Erfassung bis zur VR-Visualisierung wird hier ausführlich beschrieben, wobei der Schwerpunkt auf der 3D-Modellierung der Höhle und der Integration in eine VR-Umgebung liegt.

\section{Introduction}

The mapping and modelling of complex cave geometry is traditionally a challenging task. Since the foundation of speleology as a scientific discipline, various methods for mapping caves have evolved in line with advances in surveying instruments. Basic methods were the freehand drawings, followed by the use of simple traditional surveying instruments such as compasses, tapes and clinometers. The introduction of total stations led to improvements in accuracy when capturing these complex geometries. Whilst image-based photogrammetric surveying can also be used for caves, the difficulty of achieving homogeneous lighting conditions is a limiting factor. In recent years, high-resolution terrestrial laser scanning (TLS) technology has revolutionised cave surveying by enabling the 3D mapping of such complex environments.

Turkey was crucible for numerous civilizations that shaped human history and boasts a wealth of tangible and intangible cultural heritage. The soil underfoot is itself a complex layered record bearing the oldest known traces of humanity. Excavations at Istanbul's Yenikapı have placed Istanbul's origin at around 8000 years ago, while discoveries at Göbeklitepe in Urfa have recovered remains some 12,000 years old. These discoveries have led to the rewriting of world history (Ulusoy Binan 2017). The inventory of cultural assets is increasing with the discoveries added every day in Istanbul. These cultural heritage resources, which are the common asset of humanity, must be protected and documented to be transferred to future generations. In this respect, BIMTAŞ, a company of the Greater Municipality of Istanbul, generated a virtual 3D model of the İnceğiz cave for the Istanbul City Government, with the aim of promoting the monument to tourists. This 3D model has been processed in collaboration with the Photogrammetry \& Laser Scanning Lab of the HafenCity University Hamburg, Germany, to develop a VR application for the immersive and interactive visualisation of the historic caves in Istanbul using the new HTC Vive Pro VR system as a new kind of knowledge dissemination.

\section{Previous Work}

Numerous studies have been carried out with the help of TLS technology since its invention. A detailed and comprehensive review of these can be found in Mohammed Oludare and Pradhan (2016). However, some of them will be mentioned here to show the content and the aim of the previous survey projects.

Gonzalez-Aguilera et al. (2009) provide detailed descriptions about their laser survey of two complex and irregular Palaeolithic caves: Las Caldas and Penade Candamo in Oviedo, Spain. A medium-range terrestrial laser scanner based on a time-of-flight principle Trimble GS200 scanner (scan density of $20 \mathrm{~mm}$ ) was used together with the highresolution Sony DSC F828 digital camera for data acquisition inside the caves. From these data were produced cross sections, triangular meshes, 3D surface models, and colour ortho-images. In addition, virtual fly-throughs including visualisations of intensity point clouds, wireframe models and textured models were generated. A total of 2 months were required to complete the recording and modelling of Las Caldas and Pena de Candamo caves.

Buchroithner and Gaisecker (2009) discuss the 3D surveying of two large cavities, with somewhat complex 
geometry, in the Dachstein cave, Styria, Austria. The laser scanner Riegl Z-420i was used for data acquisition, while the point clouds of overlapping laser scans were registered using the software RiScan Pro. After registration, triangulating the point cloud results in a 3D surface model, which was then used for volume calculation, contouring and profiling. This model represents a database for the modelling of well discharges in karst hydrology and photo-realistic visualisations. The authors note the challenges of working in the cave due to its temperature, air humidity, dirt and dripping water in addition to the transportation of the heavy scanner Riegl LMS Z-420i through its $60 \mathrm{~m}$ length.

The Wonderwerk Cave in South Africa was fully scanned with a Leica scanner HDS3000 and a 3D model was generated as part of the African Cultural Heritage Sites documentation project (Rüther et al. 2009). The output allowed the generation of sections through the 3D model along any chosen axis and at any location, in both point cloud and surface format. In this way, areas and volumes of any section of the cave and the surrounding hill can be determined to derive the overburden of the cave. In addition, 3D visualisations could be made from any selected point within and outside of the cave. Furthermore, projecting images over parts of the surface or the entire surface allowed excavated sections and rock art, among other features, to be shown.

Lerma et al. (2010) present the 3D laser scanning of Parpello cave in Valencia, Spain. The cave houses more than 5600 carved and painted plaques, spanning an archaeological time frame of more than 1000 years. The TLS data acquisition of the Parpello cave site was conducted using a Faro LS 880HE scanner. During scanning, photos of the whole cave were taken by Canon EOS D60 camera with the resolution of $3072 \times 2048$ pixels using a Sigma wide-angle lens with a focal length of $15-30 \mathrm{~mm}$. The software Faro Scene was used for point cloud processing. For triangular meshing, 3D solid model and photo-realistic model generation, the in-house software FotoGIFLE, developed by the Photogrammetry and Laser Scanning Research Group at the Polytechnic University of Valencia, was used. The authors conclude that photo-realistic 3D models were superior to 2D digital images in allowing users to manipulate the data immediately in 3D. This type of 3D documentation may help with future interventions inside the cave, where the use of 2D data on its own may be restrictive.

The archaeological Bronze Age cave "Les Fraux" in Dordogne, France, is likely one of the most studied caves in Europe, with a large interdisciplinary research team (Grussenmeyer et al. 2012). The cave consists of a network of constricted horizontal corridor adorned with a range of historical artefacts including ceramics, metal deposits, fireplaces and parietal engravings meticulously placed over a distance of more than $1000 \mathrm{~m}$. Documentation work began in 2007 and lasted 6 years (Burens et al. 2013). Three laser scanners (FARO Photon 80, FARO Focus3D and Trimble Spatial Station) and close range photogrammetry were used to produce the geometric and virtual 3D model of the cave (Grussenmeyer et al. 2010; Grussenmeyer and Guillemin 2011). In line with the objectives to deliver a system that would be useful for the highly multidisciplinary team, Grussenmeyer et al. (2012) proposed an adaptable recording and processing workflow to integrate information collected at different scales within the 3D model of the cave. Burens et al. (2013) further demonstrated the possibility to combine data by merging topographic, archaeological and magnetic information in the same visualisation system.

Cosso et al. (2014) conducted a detailed exploration of Pollera cave with the aim of improving and promoting tourism in this area as well as updating the available data by 3D surveying the more accessible rooms. The survey was carried out using a Z +F IMAGER ${ }^{\circledR} 5010$ laser scanner, while the registration of point clouds was executed using the $\mathrm{Z}+\mathrm{F}$ LaserControl ${ }^{\circledR}$. Subsequently, two different free and open source software packages, MeshLab and CloudCompare, were used for filtering, merging and meshing the point clouds. Using this 3D model, cartographic datasets such as vertical or transversal sections can be extracted, as well as areas and volumes calculated. In addition, the model may be used in multimedia products such as movies, images or scenes for 3D virtual tours, also considering that many activities of HD video filming have already been carried out in this context.

Zlot and Bosse (2014) present the SLAM-based mobile mapping of Australian Jenolan and Koonalda caves using Zebedee handheld system consisting of an infrared laser scanner Hokuyo UTM-30 LX (wavelength $905 \mathrm{~nm}$ ) mounted on a suspension. This system includes a MicroStrain 3DMGX3 industrial grade MEMS IMU. In addition to the handheld device, Zebedee hardware includes a small laptop for sensor operation and data logging. A lithium-ion battery pack, which provides more than $10 \mathrm{~h}$ operation, powers both sensor and laptop. The scanning device is held in the operator's right hand, while a battery pack and a small laptop for data recording are carried in a backpack. The 3D point cloud mapping of the Jenolan caves involved some $15.5 \mathrm{~h}$ of data collection over a $17.1 \mathrm{~km}$ traverse, resulting in a point cloud of more than 2.7 billion points. Unlike many of the caves at Jenolan, Koonalda cave does not contain significant speleothem formations, and typically it is fairly dry, with the notable exception of lakes in the lower level. The 3D watertight surface model of this cave consists of approximately 300 million points. This study is a good example of the use of mobile laser scanning systems in conditions where GNSS is not available.

Gallay et al. (2015) note the advantages of using terrestrial laser scanning to rapidly map the complex system of the Domica Cave in Slovakia. They use the Faro Focus ${ }^{3 \mathrm{D}}$ S120 
scanner for scanning and the Faro Scene software for data processing and georeferencing. The semi-automatic registration of all scans was carried out using reference spheres placed in each scene with an overall accuracy of $2.24 \mathrm{~mm}$ (RMSE). The 3D cave surface model was generated from a registered laser point cloud for volumetric and spatial analyses in a GIS platform.

Basantes et al. (2017) describe the generation of a 3D model of the Elvandi cave, located in the province of Napo, Ecuador, using a Faro Focus ${ }^{3 \mathrm{D}}$ laser scanner. For data processing, Faro Scene software was used. A virtual model was generated using Revit, allowing users to interact with the environment. The virtual environment measures approximately $200 \mathrm{~m}$ in length and has an average precision of $4.14 \mathrm{~mm}$ from the pairs of scans, allowing the irregular path of the cave to be accurately depicted. The original point cloud contains 300 million points and a data volume of almost 10 Gbyte, though filtering reduced the data to 27 million points and two Gbyte.

Shults et al. (2019) present the mapping of the Kyiv Perhersk Lavra cave, located under an orthodox monastery in the Ukraine. The total length of the caves is around 450 metres. Laser scanning was carried out with a Leica ScanStation and the scans processed using Cyclone 5.6, with an RSME of $4 \mathrm{~mm}$ for scan registration. Using the entire 3D point cloud, a Triangular Irregular Network model was generated with a grid size of $50 \mathrm{~mm}$ and $25 \mathrm{~mm}$, respectively. A 3D solid model and a plan with the scale 1:500 including cross sections were generated using the software Realworks Survey. The authors claim that the laser data obtained plays an important role, besides the above-mentioned purpose, in preserving the historical and cultural heritage. In the future, these data can also serve as the basis for creating a 3D BIM of the cave complex, as suggested in Banfi et al. (2017) and Dore and Murphy (2017). In addition, a 3D interactive GIS model of the cave complex may be produced.

Considering the studies described above, it is immediately clear, to the authors' knowledge, that the 3D recording and visualisation of cave monuments have not received extensive research. Although a recent publication by Nocerino et al. (2019) focusses on the 3D visualisation of the underground semi-submerged cave system "Grotta Grusti" in central Italy, little information concerning the VR implementation steps is presented in the paper, as well as lacking a full discussion of the challenges. Their study used a Leica HDS7000 timeof-flight continuous wave laser scanner for the dry entrance part of the cave, while the semi-submerged parts of the cave were surveyed photogrammetrically by a stereo-camera system consisting of GoPro Hero4 cameras mounted on a rig. Two image strips above and five strips below the water with around 60-80 percent overlap were acquired. For the rest of the chamber (those parts far from the water level, such as the ceiling), images taken by a Nikon D750 camera in a NiMAR water proof housing and coupled with a more powerful strobe unit were utilised. From these data, a fully merged and textured model of the whole cave (above and under water) was able to be generated. Using this photorealistic 3D model, an immersive virtual tour was realised using the Unity game engine. This VR experience was shown to increase the sense of presence of the user within the environment and to allow a better appreciation of the smaller details of the underground structures.

Virtual Reality (VR) offers an attractive opportunity to visit objects or places of the past (Deggim et al. 2017a) that today remain difficult to access, often from perspectives that are impossible to experience in real life. Moreover, these powerful features are increasingly being implemented and extended in the context of so-called "serious games", which seek to create entertaining educational experiences (edutainment) through embedding information within the virtual world and constructing narrative and interactive dimensions of the experience (Anderson et al. 2010; Mortara et al. 2014; Liarokapis et al. 2017).

Cultural heritage sites make ideal subjects for realistic interactive visualisations in Virtual Reality as they are already the focus of tourism, whether they are landmarks themselves or exhibited in museums. Several examples of the VR visualisation of historical spatial data have already been published. Gaitatzes et al. (2001) present visits to objects in the past as an attractive opportunity using CAVEs. One of the first virtual museums, presenting an old town house in the town of Bad Segeberg, was developed for the HTC Vive Head Mounted Display (HMD) (Kersten et al. 2017b). Two historic towns (as well as the surrounding landscape) were also reconstructed as VR experiences: Duisburg in the year 1566 (Tschirschwitz et al. 2019b) and Segeberg in the year 1600 (Deggim et al. 2017b). Two religious cultural monuments are also available as VR experiences: the Selimiye mosque in Edirne, Turkey (Kersten et al. 2017a) and the wooden model of Solomon's temple (Kersten et al. 2018). In addition, more recently, a virtual model of an Ottoman fortress, Rumeli Hisarı, located at the Bosphorus in Istanbul, has been built for VR and shown at several exhibitions (Tschirschwitz et al. 2019a). Edler et al. (2018) present a workflow for constructing an interactive cartographic VR environment for the exploration of urban landscapes. Large landscapes have also formed the subject of interactive VR visualisations, such as that of the arctic Clyde inlet in Canada (measuring 160 by $80 \mathrm{~km}$ in size) (Lütjens et al. 2019).

\section{The İnceğiz Caves of Istanbul}

Among the numerous ancient ruins in the region of the Çatalca District on the European side of Istanbul are the İnceğiz caves, carved out of the rocks in the Karasu valley 
(Fig. 1). This cave system, which consists of five groups of cave structures, is known to have served as a cave monastery and rock church (Dirimtekin 1957). The İnceğiz caves, which were formed by processing and enlargement of natural rock cavities by people throughout years, were used as a living and praying area by them.

Today, there is much excavation and research activity in this region, and archaeological sites continue to be identified and recorded (Aydıngün et al. 2015). The wider area of the caves, containing an ancient settlement, a necropolis, an ancient road, waterways and a water source was declared a first-degree archaeological site by the Cultural Heritage Conservation Board No. 2 in 1994. The archaeological findings suggest that the settlement was active between the end of fourth and beginning of fifth centuries A.D. (Pasinli et al. 1994).

According to excavations and surveys conducted in the region, Maltepe is understood to have been a Thracian village, inhabited during the Hellenistic and Roman periods (fourth century B.C.-fourth century A.D.). It is thought to have been associated with the cult of Aphrodite, and to have had a close commercial relationship with the cities of Byzantion and Perinthos (Pasinli et al. 1997). The artefacts found in this region are currently exhibited in the Istanbul Archaeological Museum.

Human occupation of the natural İnceğiz caves are thought to have started with the settlement of the area in the twelveth century B.C. Beginning in the fourth century A.D., the caves were used as monasteries. The eleventh and twelveth centuries witnessed the most intense use of these monastries, seeing the building of additional floors in the caves. During this period, the caves became a place of worship for Byzantines. The caves ceased functioning as monasteries at the start of the fourteenth century A.D. (Dirimtekin 1957).

During the 1970s, the caves were subject to illegal excavations, as well as being used as a film set for several movies. It is understood that nobody took care for their conservation during this period. In the 2000s, the area began to be used as a recreation area, with the laying out of cycling and walking routes, despite the imperative that the caves be preserved naturally within the wider context of their cultural landscape. The erodible nature of limestone and lack of security in the region nonetheless led to the structure being damaged. Renewed conservation efforts began in 2018 with the documentation and the re-evaluation of the area as a cultural landscape.

In total, there are five groups of cave structures in the region. However, in this paper, only the first group of the caves (Fig. 1) is considered, though documentary work for the other caves is under way. In the following section, the structure of the first cave group is introduced in detail. The cave was carved into a limestone block rising at a $90^{\circ}$ angle to the Karasu creek near the village of İnceğiz. Over time, it was expanded to become a 5-storey structure through enlargement of the natural rock cavities by humans. In subsequent years, however, it was significantly eroded by the environment. The cave has two façades to the west and north (Fig. 2, left and centre). The remains of stairs leading up to the second floor on the front façade indicate that the exit/ entrance to the upper floors of the original cave was here (Fig. 2, right).

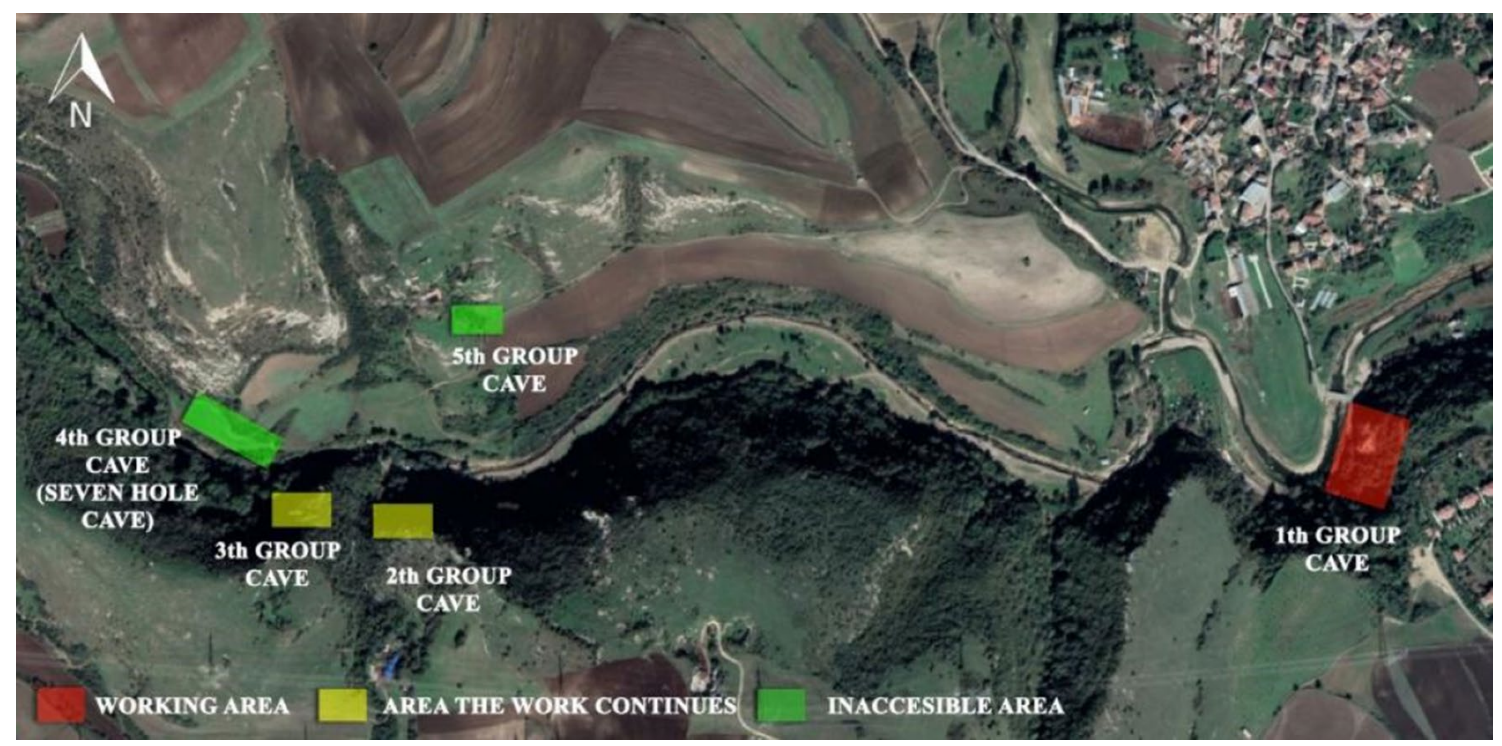

Fig. 1 Location of the İnceğiz caves complex near Çatalca in the western part of Istanbul, with Cave Group 1 on the right (working area shown here in red) 
Today, access to the first and second floor is provided by wooden stairs, added later. From the south part of the cave, it is possible to climb to the upper parts (Fig. 3, left). Three large niches are carved into the stone at the entrance level, and are directly accessible from the outside (Fig. 3, right).

On the ground floor are located four rooms, including a side room, worship area, corridor and a further room. Access to the worship area is via a staircase carved in the rock (Fig. 4, left). The worship area (measuring about
$28 \times 9 \mathrm{~m}^{2}$ in size) consists of a central apse and two adjacent apses. Due to the shape of the rock, these apses are not completely aligned. There are cavities in the apse walls. The side walls of the apse end at the ground and the ceiling continues forward (Fig. 4, centre). In this room, a niche was carved into the wall located in the south of the chamber above a basin carved into the floor, which was thought to have been a baptismal font (Fig. 4, right). The
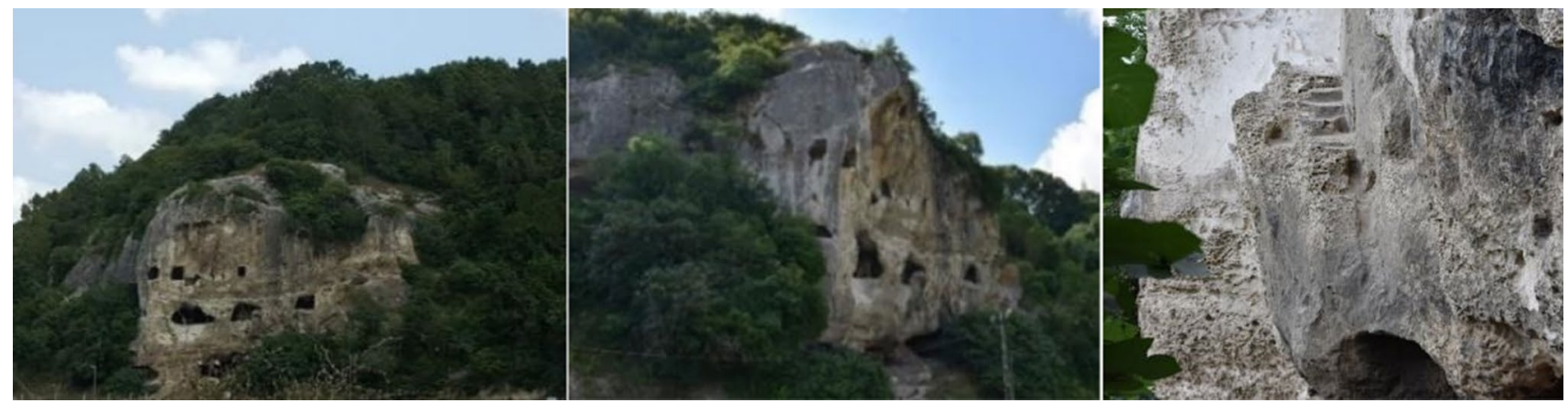

Fig. 2 Group 1 caves — west façade (left), north façade (centre), and remains of staircase (right)
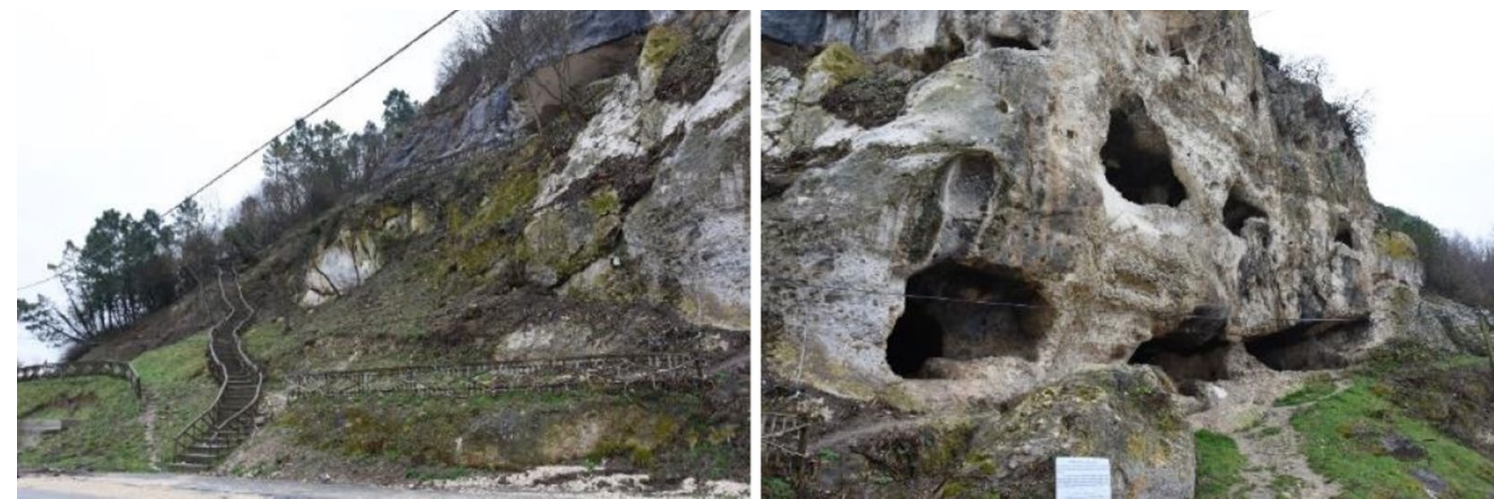

Fig. 3 Wooden ladder added later (left) and entrance level niches (right)

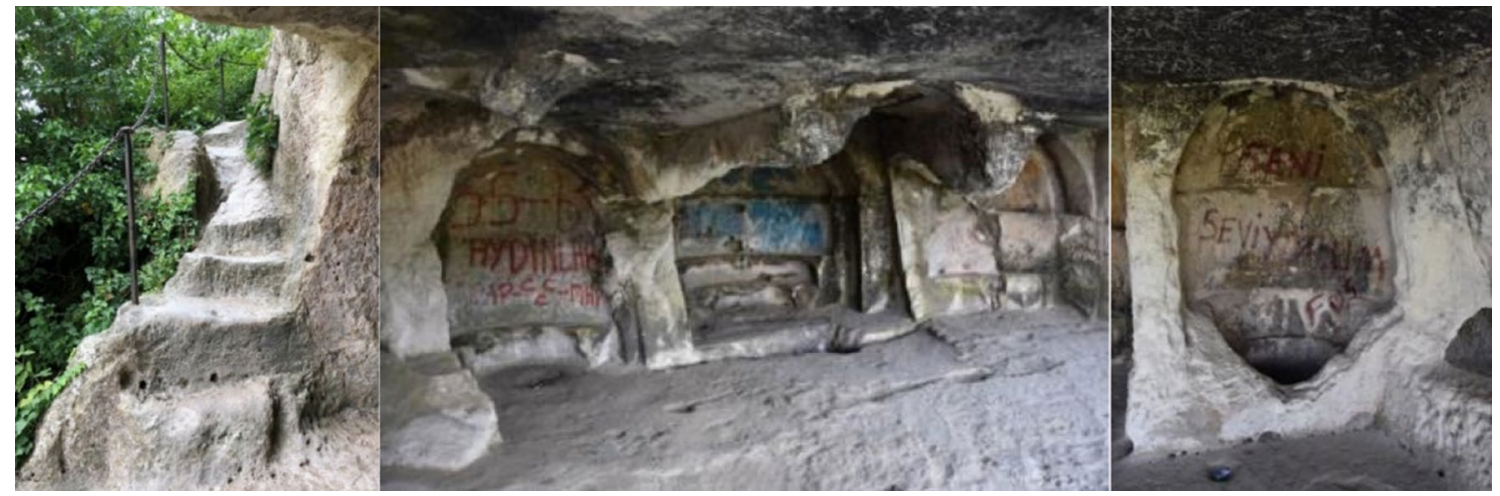

Fig. 4 A rock staircase (left), worship area (centre) and baptismal font (right) 
Fig. 5 Chain railings (left), stairway from ground to first floor (centre) and wooden staircase (right)

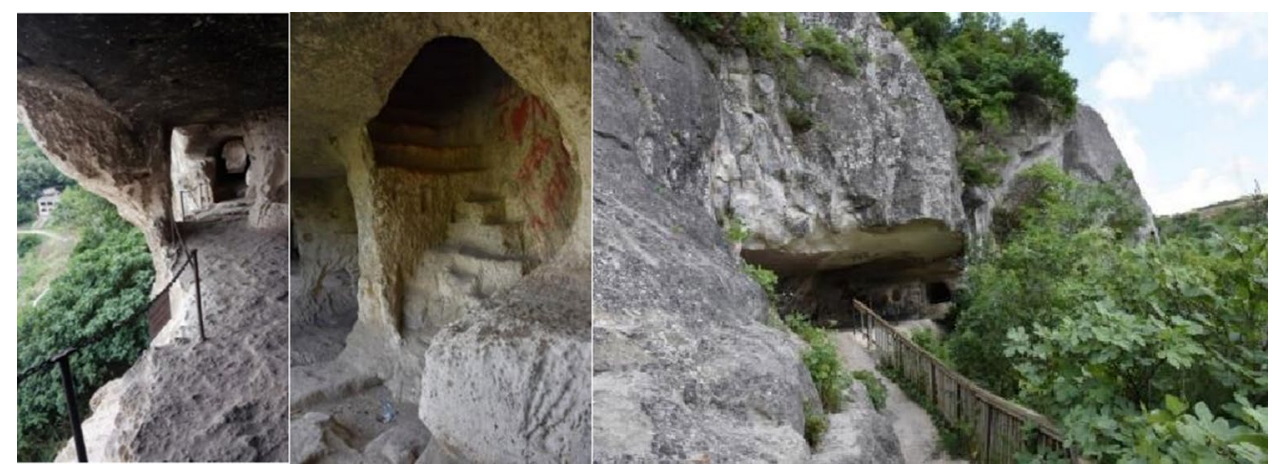

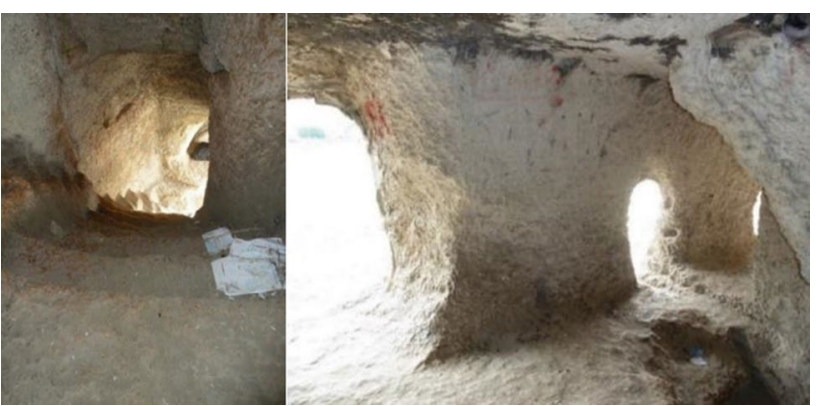

Fig. 6 Stairs leading up to second floor (left), and second floor main worship space (right)

writing visible on the walls is unfortunately due to visitors without any regard to the history of the site.

The openings of the cave are now closed off with chain railings (Fig. 5, left). A steep staircase leads to the first floor from the ground floor (Fig. 5, centre). Another room on the ground floor can be accessed using a wooden staircase (Fig. 5, right).

A staircase from the first floor leads to the second (Fig. 6, left), where a worship area was carved out (Fig. 6, right). This space was used for praying.
The third floor faces south-east (its location is shown by red circle in Fig. 7, left). This floor is thought originally to have had two chambers, but due to the lack of intermediate walls today, only one chamber is visible with a floor height of $2.45 \mathrm{~m}$. Figure 7 (middle and right) show the entrance of the third floor and its apsis.

\section{Workflow}

The following workflow was developed to generate a detailed virtual 3D model of the complete cave structure: (1) data acquisition by terrestrial laser scanning with a Riegl VZ-400 scanner, (2) registration and geo-referencing of scans using RiScan Pro, (3) segmentation of point clouds into tiles in RiScan Pro, (4) re-organisation of point cloud tiles in ReCap as preparation for modelling in 3ds Max, (5) 3D solid modelling with 3ds Max using segmented point clouds, (6) texture mapping of polygon models using $3 \mathrm{ds}$ Max, (7) data conversion for import into the Unity game engine, (8) integration of motion control and interactions in Unity, and (9) immersive and interactive visualisation of the cave in the VR system HTC Vive Pro using Steam VR 2.0 as an interface between the game engine and the HMD.

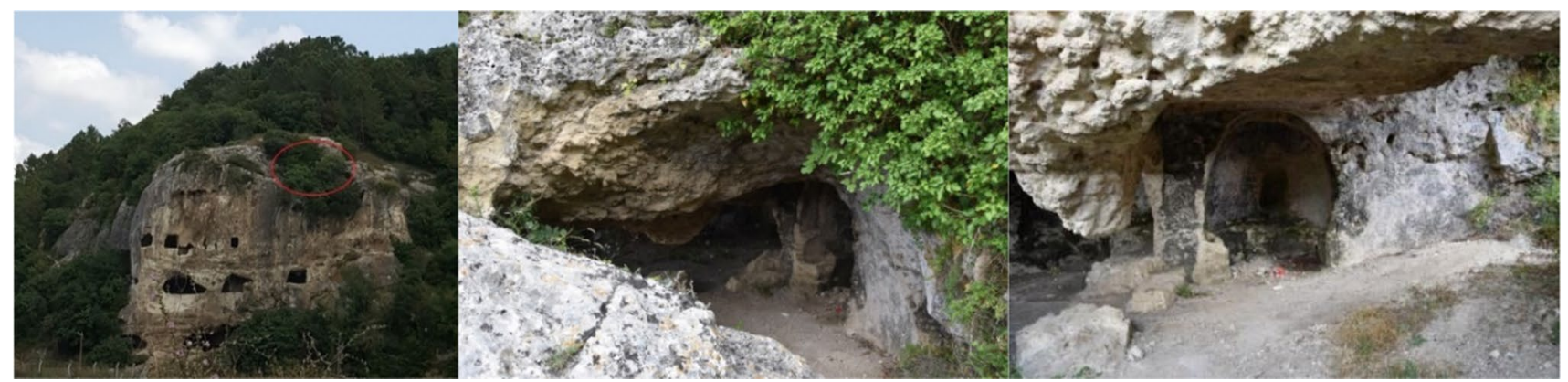

Fig. 7 Third floor location (left), third floor entrance (centre), third floor apse (right) 


\section{Laser Data Acquisition and Processing}

The scanning of the cave structure (1st group), an area of approximately $3500 \mathrm{~m}^{2}$, was performed in July 2018 using a single terrestrial laser scanning system, the Riegl VZ-400, and four staff members from BİMTAŞ (Fig. 8). In total, 46 scans of the interior and 50 scans of the exterior of the cave were acquired using a scanning density of $4 \mathrm{~mm} @ 50 \mathrm{~m}$ in average (point density of $4 \mathrm{~mm}$ at a distance of $50 \mathrm{~m}$ ).

Only on some scan stations were reflective targets used to geo-reference the point cloud. For the later colourising of the laser scanning point clouds, an integrated Nikon D610 camera was used on top of the Riegl scanner taking five images in $360^{\circ}$ view per scan. Figure 9 shows the colourised point clouds of the interior and exterior of the cave, respectively. All scans have been registered with a precision of about 2-3 mm in the Riegl RiScan Pro software. In total, a data volume of 67 Gbyte, consisting of 636 million laser points, was produced and subsequently processed in RiScan Pro over approximately 1 week by two people. To geo-reference the laser scan point clouds for the interior and exterior of the cave, as well as to integrate the data into the national coordinate system, a 3D geodetic network including the reflective targets was measured by electronic total stations and GNSS before scanning. During the scanning, some parts of the cave, which were not accessible from the ground, were scanned from a crane (Fig. 8, right).

Following the processing stage, the point cloud was sectioned with different cutting planes along horizontal and vertical planes. Figure 10 shows the extracted cross sections. ZMap software from Menci Software Srl (Arezzo, Italy) was used to generate 2D CAD drawings of the cave structure. Figure 11 (left) shows a technical drawing from a perpendicular view of the outer façade of the cave. Figure 11 (right) shows an aerial view of the cave and the surrounding area including the creek, road, green areas and ladders.

\section{360-Degree Panoramic Gigapixel Photography}

To document the site in more detail, $360^{\circ}$ gigapixel photography was employed in addition to laser scanning and 3D modelling. For this, a Canon EOS 7D Mark II camera

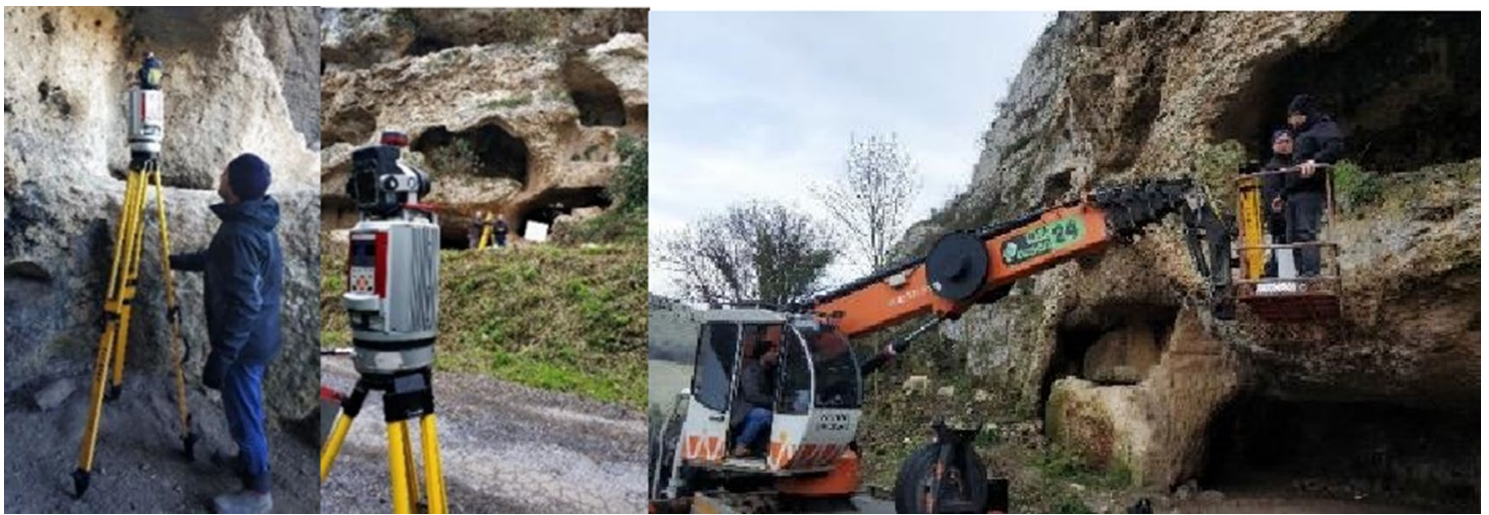

Fig. 8 Terrestrial laser scanning using the Riegl VZ-400 inside (left), outside the cave (centre) and in hard-to-reach areas using a crane (right)

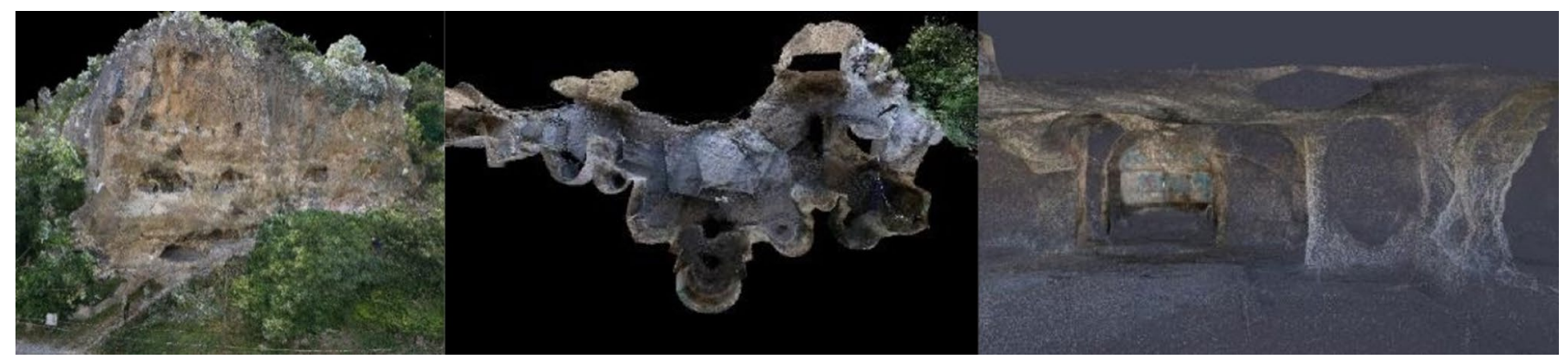

Fig. 9 Colourised point cloud data from TLS outside (left) and inside the cave (centre and right) 

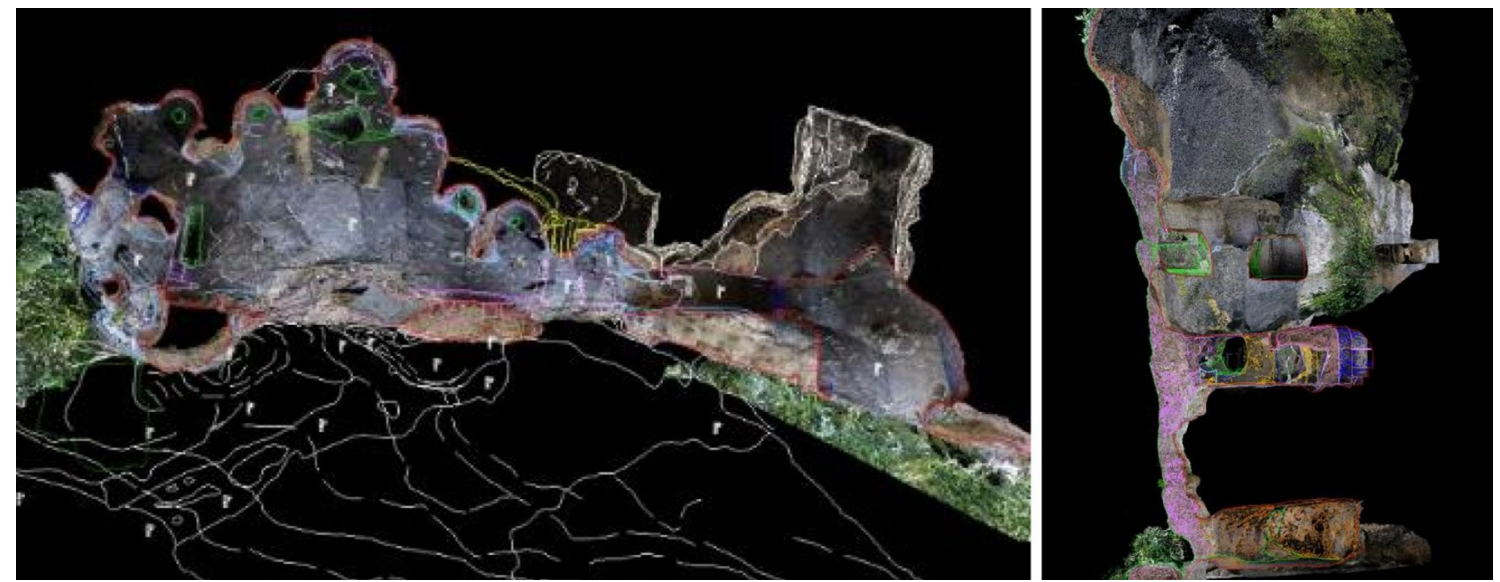

Fig. 10 Horizontal section (left) and vertical section (right) of the cave system in ZMap software
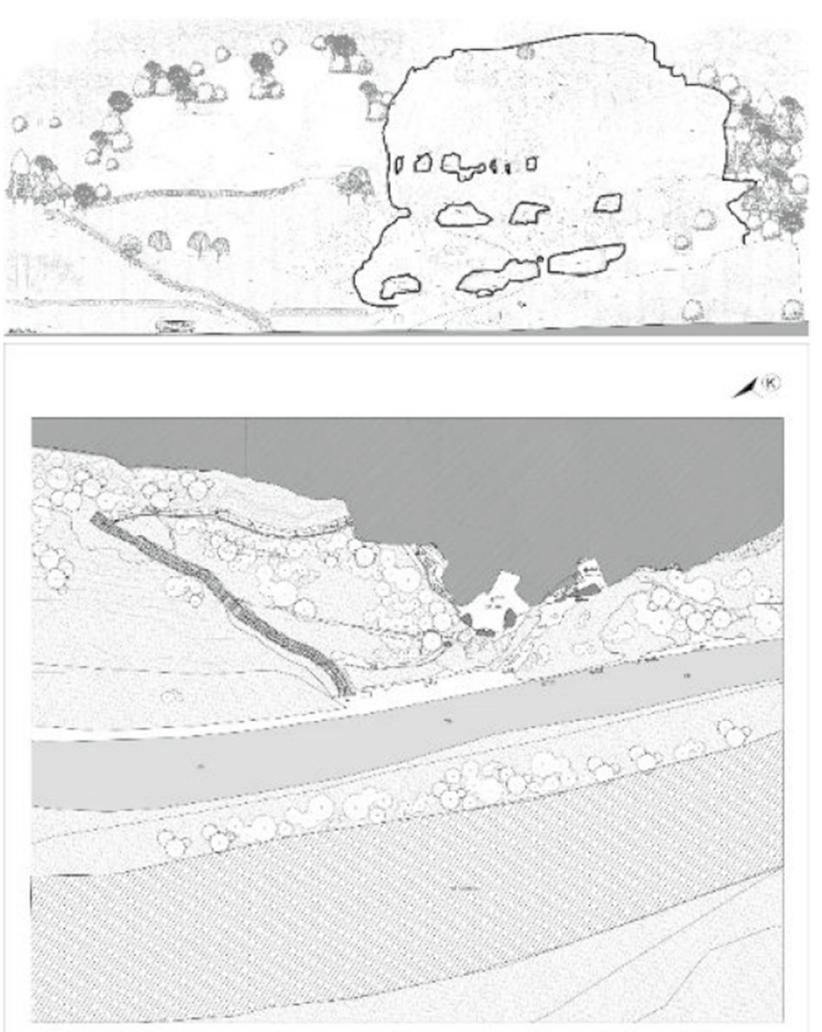

VAZIYET PLANI

Fig. 11 2D CAD drawing and laser point cloud for the front façade (top) in ZMap software and architectural 2D CAD drawings presenting the situation plan (bottom)

with a Canon EF 70-200 mm f/2.8 zoom lens was used. This camera features a 20.2 megapixel CMOS sensor, resulting in $5472 \times 3648$ pixels per photo. A full $360^{\circ}$ panorama shot was taken automatically with Roundshot VR in about 10 min, excluding the time needed for setting up the device for image acquisition.
To fully document the cave system, 63 camera stations were used outside and 138 inside the cave. The panorama photos include related XML files generated by the VR drive, allowing us to define the exact position of every image as well as the image capture sequence. The stitching of the panorama photos was carried out using the software PTGui from New House Internet Services B.V. (Rotterdam, The Netherlands), aided in problematic areas by manual control point measurements. To maintain the high resolution, each panorama image was exported with .psb extension, which could then be imported into Adobe Photoshop for further processing (including colour and illumination corrections). The data volume of each panorama generated is approximately 422.5 megapixels.

After image processing, all panorama photos with the . psb extension were then further processed by the software Panotour Pro, from Kolor, to convert the large image files into smaller mosaic tiles suitable for being viewed on the internet as $360^{\circ}$ panoramas using $3 \mathrm{D}$ glasses or in browser. Two examples of the panorama photos are shown in Fig. 12. These gigapixel panoramas were also used to provide additional visual information about the cave structure for more accurate 3D modelling.

\section{3D Solid Modelling}

The final 3D model of the entire cave structure, as illustrated in Figs. 13 and 14, was built over the course of 3 months by two employees. Geo-referenced point clouds were imported into Autodesk ReCap and Geomagic studio (for the smaller details) to generate the 3D meshes. These meshes were then used as the basis for solid modelling in 3ds Max, to derive the final 3D model and associated CAD drawings. Similar workflows have already been presented elsewhere by Dursun et al. (2008), Kersten et al. (2009) and Kersten et al. (2017a). 


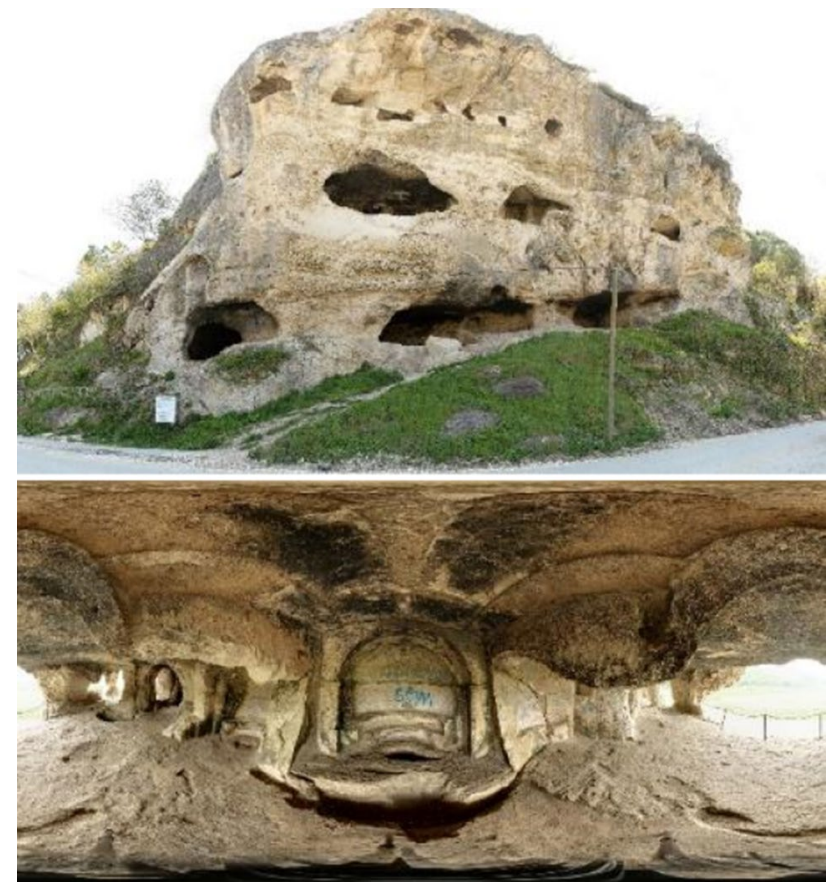

Fig. 12 Gigapixel panorama of the cave-outdoor (top) and indoor (bottom)
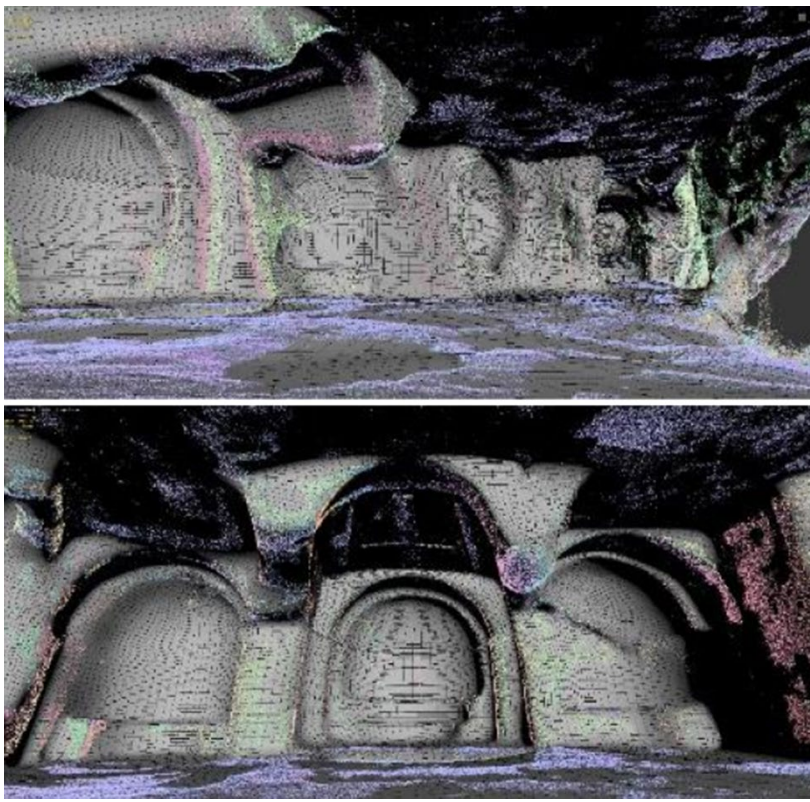

Fig. 13 3D interior model generated from the point cloud in 3ds max

For the texture mapping of the solid 3D model of the cave, additional photographs were taken using a DSLR camera Canon EOS 50D with an 18-55 mm zoom lens during the field campaign. A total of 300 photos were taken at a resolution of $4752 \times 3168$ pixels by two people in 3 days. These images were radiometrically enhanced in Photoshop before texture mapping. Using these image files, polygonal surfaces were mapped with the unwrap UVW modifier technique in $3 \mathrm{ds}$ Max.

\section{Generation of a Video Sequence}

To generate a video sequence, the 3D model was exported as an FBX file for visualisation using the software Lumion from Act-3D B.V. in Warmond, The Netherlands. Lumion enables users to create videos and images without any prior training by editing the generated environment in real-time and by extremely fast rendering using GPU rendering technology. All atmospheric and light effects were prepared in this software before rendering. The complete rendering took 2 days using three computers with GTX 970 graphics card, 16 GB RAM and Intel i7 4700K processor. A video sequence of 5 min with the resolution of $1920 \times 1080$ pixels was produced in AVI format, producing a data volume of 0.5 Gbyte. Four perspective views of the cave generated with Lumion are shown in Fig. 15.

\section{The Unity Game Engine and HTC Vive Pro VR System}

The Unity game engine was used to realise the Virtual Reality experience. A game engine is a software framework designed for the creation and development of video games for consoles, mobile devices and personal computers. The core functionality typically provided by game engines include a rendering engine allowing 3D models and spatial data to be displayed as 2D or 3D graphics, a physics engine or collision detection (and collision response) for the interaction of objects, and an audio system to emit sound, scripting, animation and networking. Game engines offer the ability for users to control the course of the game or simulation through interaction and are furthermore responsible for the entire visual appearance of the virtual world.

The solid 3D model of the cave was transferred as an.fbx file to Unity. The exported model had 650,642 polygons, a figure small enough to guarantee sufficient computer performance during VR visualisation. The final scene was exported as an executable file for the HTC Vive Pro VR system, as illustrated in Fig. 17.

The HTC Vive Pro (developer.vive.com) is a Virtual Reality headset (Fig. 16) for room-scale VR. BIMTAŞ bought this system for a price of about 1500 EUR in March 2019. Basic components are the headset for the immersive experience, two controllers for user interactions and two base stations for tracking the user's movement. The principal development from previous versions of this headset is the improved cable management. In particular, the big bundle of 


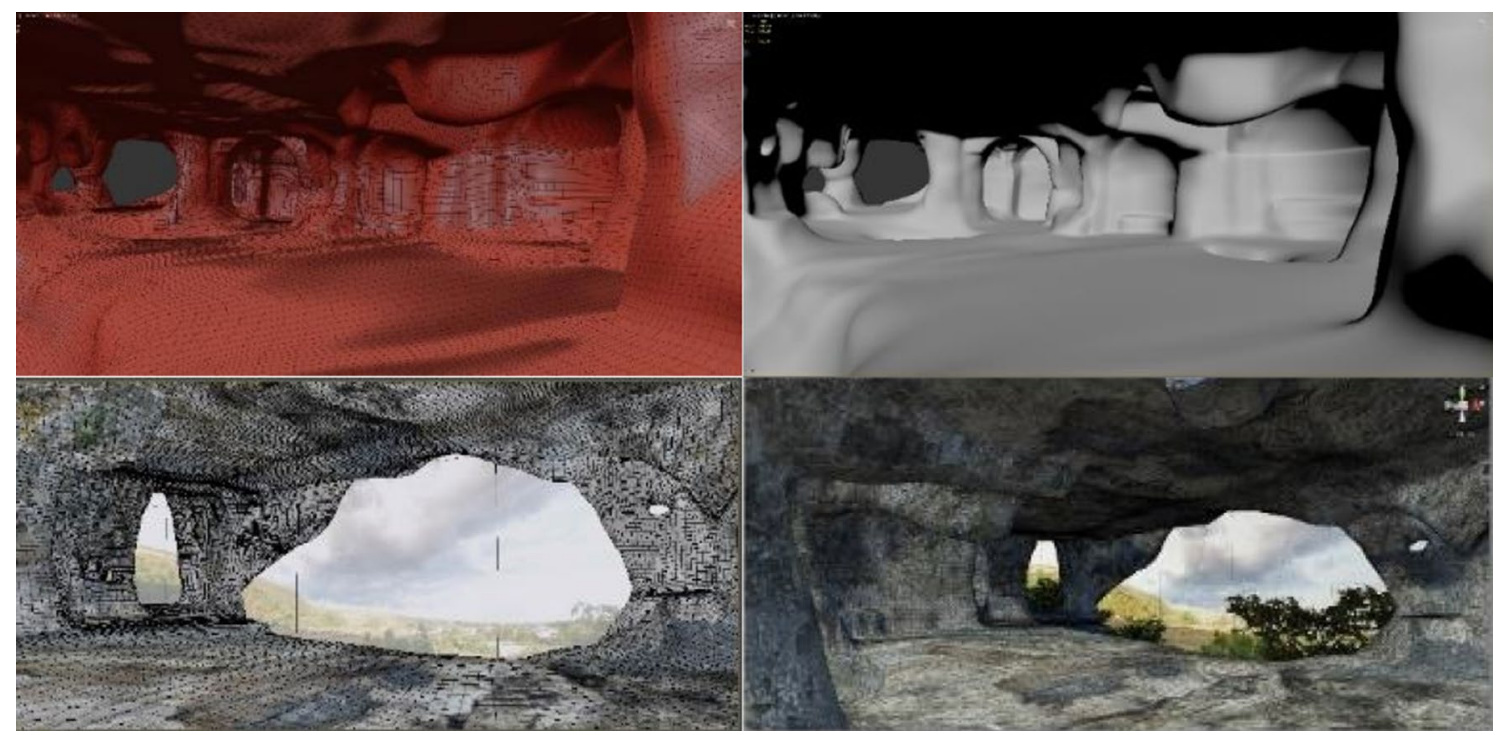

Fig. 14 Modelling process of the cave-meshing (top left), rendering (top right) and texture mapping (bottom left) in 3ds max and the final coloured Unity scene of the VR application (bottom right)

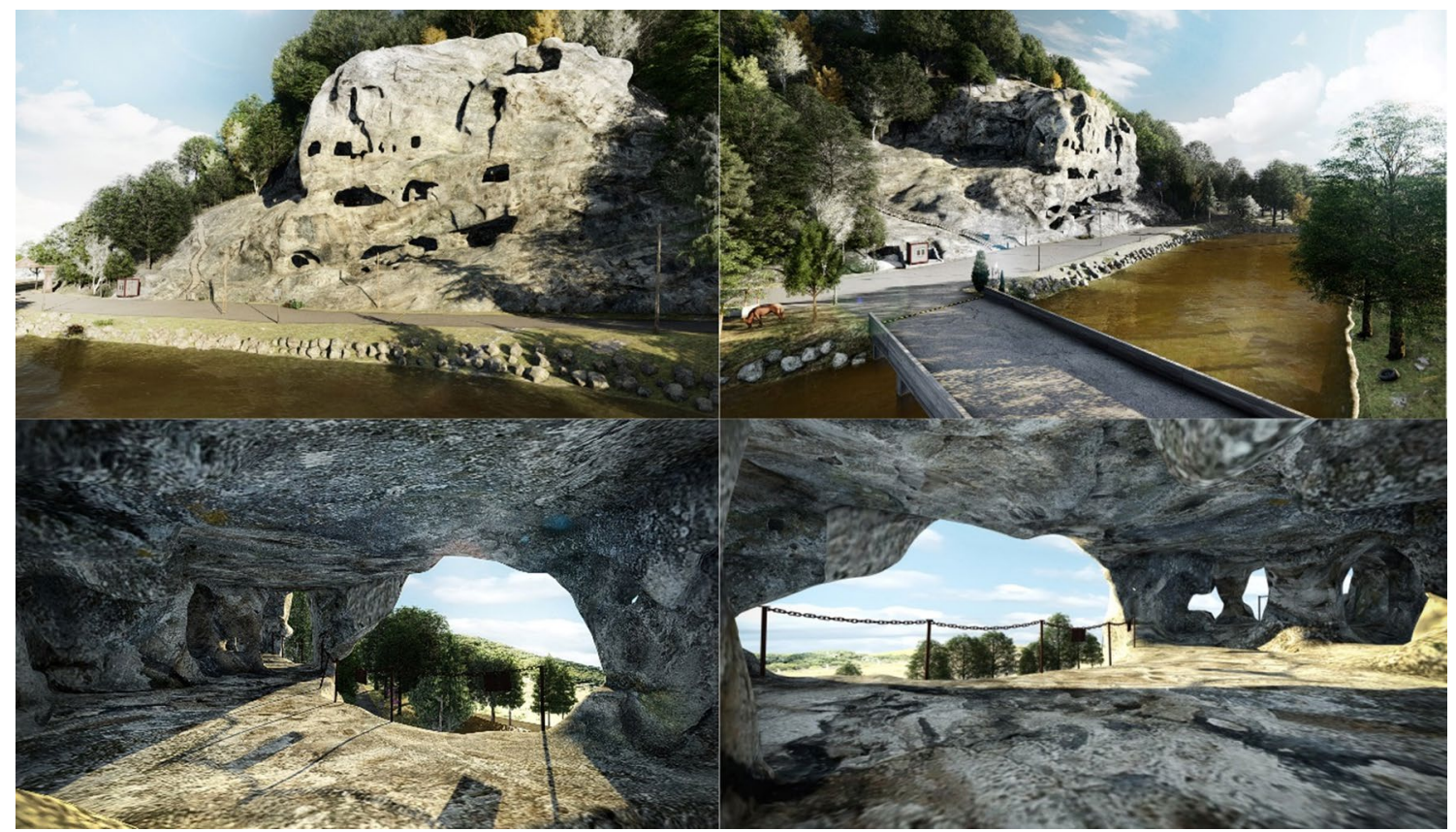

Fig. 15 Interior and exterior views of the cave generated in Lumion software for a video sequence

cables that were positioned from the top of the wearer's head to the middle top of the goggles has been replaced in the Vive Pro with a slim cable neatly routed around the left side of the headset and connecting to the left side of the goggles.

The technical specifications of the HTC Vive Pro are summarised in the following: (a) dual AMOLED 3.5" diagonal screens with a field of view of approximately $110^{\circ}$, one per eye, each having a display resolution of $1440 \times 1600$ pixels with a refresh rate of $90 \mathrm{~Hz}$, (b) positioning sensors including gyroscopes, (c) 6 by $6 \mathrm{~m}$ tracking space for user operation using two base stations for $360^{\circ}$ tracking volume, (d) SteamVR 2.0 running on Microsoft Windows as the platform/operating system, (e) two wireless motion controllers, (f) Vive Pro headset, on-ear headphones and dual integrated microphones to enable better input and collaboration, and (g) QC powerbank (which powers the headset via wireless adapter), connection cable and the kit together with extended head pillow for wireless adapter. Figure 17 (left) shows the 


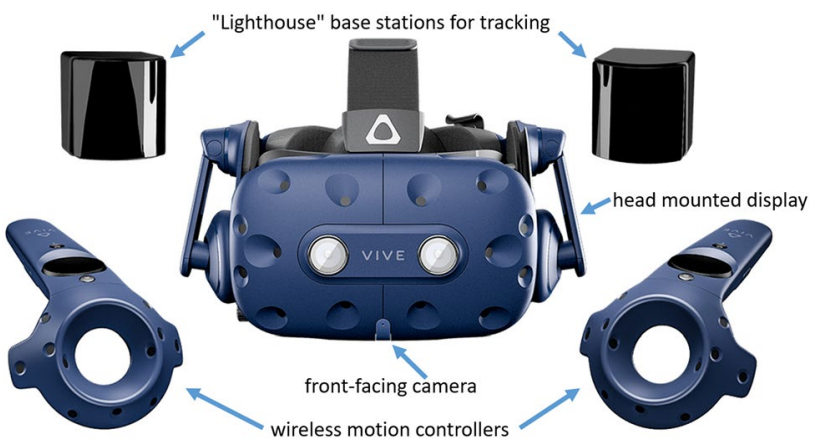

Fig. 16 The components of the virtual reality system HTC Vive Pro (www.vive.com)

Virtual Reality System HTC Vive in action, while a user navigates through the cave model.

\section{The VR Implementation}

The textured CAD model generated in $3 \mathrm{ds}$ Max was imported into Unity with several minor adjustments in the material parameters. Even with extensive research in the field of game engines and game design, the transformation of 3D models into game engines remains problematic. Furthermore, the development of interactive virtual environments is both time consuming and technically a difficult task. Locomotion in VR is also an area of active research. McCaffrey (2017) gives an overview of various locomotion methods and their implementation in a different game engine (Unreal Engine 4). Most experiences implemented on this hardware, described in Sect. 9, use natural locomotion where real walking movements are translated into virtual movements and the limitation of the tracked physical space is extended by teleportation. The movement feature was implemented using the SteamVR package downloaded from the Unity asset store. The VR experience produced, therefore, offers the possibility to visit the cave from a realistic firstperson point of view, and employing intuitive interactions. It was, therefore, decided to allow the user to move freely in the space, rather than via a series of view points. To bridge long distances in the virtual space, a teleportation function was implemented (Fig. 17).

\section{Conclusions and Outlook}

In this paper, we have presented the digital workflow from 3D data acquisition to immersive visualisation of the cave system near İnceğiz, a town located in the west of Istanbul, Turkey. The İnceğiz cave is distinguished by having yielded some of the richest archaeological finds in Turkey, from the very early centuries B.C. up to the present time, and representing a variety of different uses by different cultural groups. Terrestrial 3D laser scanning was carried out using a Riegl VZ-400 laser scanner, followed by the rigorous processing of the point cloud data using various software packages. Using 3D laser point clouds in combination with panoramic photographs, a solid 3D mesh model of the cave was generated. The Unity game engine was used to build an immersive Virtual Reality experience of the site for the HTC Vive Pro VR system. This VR system allows the users to enter, explore, and analyse the virtual cave environment, providing a high level of visual and corporeal immersion without the need to visit the site in person. The challenge of the project was to find a balance between the detail of the 3D mesh and the speed at which the 3D scenes were rendered in real time, to provide a smooth experience and avoid motion sickness. Cultural heritage monuments-historic, non-existing, or remote-are ideal objects for immersive VR application due to their already-existing importance as destinations and places of interest for potential users. The Çatalca region contains the material traces of many cultures that have occupied the area since antiquity. The caves near İnceğiz can be split into five separate groups. However, in this study, only the first group of the caves was documented and visualised. Work is to be continued on the other cave groups in the future.

This VR application is - to the knowledge of the authors-the first cave in Turkey and perhaps in the world to be visualised as a 3D immersive and interactive

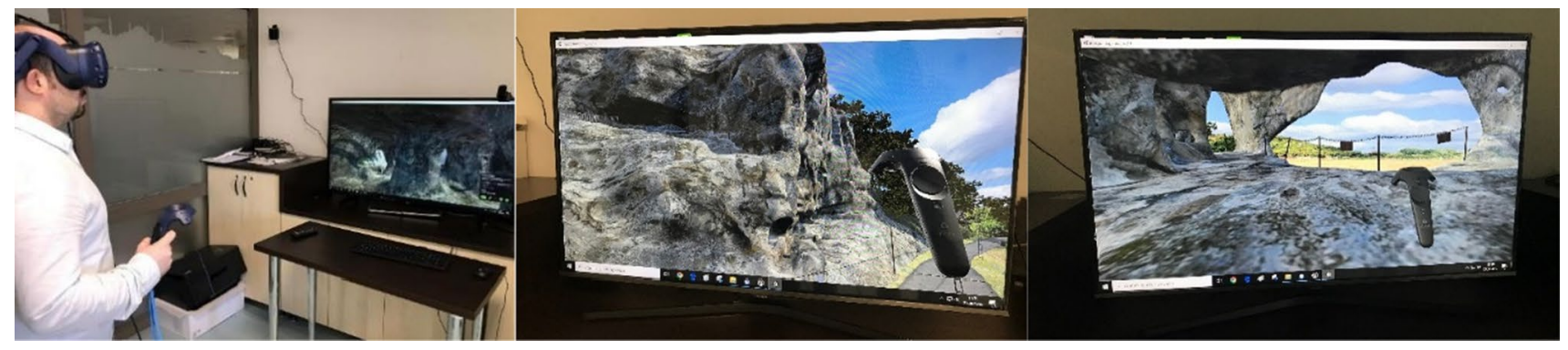

Fig. 17 User action in the VR application experiencing the cave 
experience in Virtual Reality. The main aim of this study was to generate a virtual environment of the İnceğiz Cave to promote both the conservation of the natural heritage and local tourism through VR "field trips". The sense of complete immersion in the scene increases the feeling of presence in the virtual environment and allows a more effective visualisation of the details in the cave. This virtual documentation of the historic cave may serve as a means to facilitate public engagement with the site and as a tool for the public to understand the current situation of the cultural heritage monument. For Turkey and other countries seeking to generate an appreciation of their wealth of cultural heritage assets to boost tourism revenue, virtual reality may prove to be an extremely important tool for developing this industry. Other well-known cultural heritage monuments such as the Colosseum in Rome and the Florence Cathedral are already accessible online as VR applications for the HTC Vive or Oculus Rift using Google Earth VR.

Although the process of recording the data, the detailed modelling and photorealistic texture mapping of the cave environment for VR is complex and time consuming, it is an important and innovative step in preserving the cultural heritage monument for the future. The workflow and study presented here can, therefore, be used as a prime example of and basis for a new form of documentation of Turkey's many archaeological and cultural heritage sites and monuments. The VR experience of the 3D cave model will provide a better understanding of the cave environment and its history for interested visitors. Beyond that, this VR application can be used for educational purposes for students and researchers in the field history, archaeology, and architecture, among others. This will also sensitise and encourage visitors and authorities to protect and restore other valuable monuments, therefore preserving cultural heritage knowledge for future generations. Looking to the future, the integration of additional information in the form of text, photos, video, sound, animations and user interactions, and even perhaps the integration of game mechanics or the development of a corresponding augmented reality application, may present itself as a new way of disseminating knowledge of the caves.

Funding Open Access funding enabled and organized by Projekt DEAL.

Open Access This article is licensed under a Creative Commons Attribution 4.0 International License, which permits use, sharing, adaptation, distribution and reproduction in any medium or format, as long as you give appropriate credit to the original author(s) and the source, provide a link to the Creative Commons licence, and indicate if changes were made. The images or other third party material in this article are included in the article's Creative Commons licence, unless indicated otherwise in a credit line to the material. If material is not included in the article's Creative Commons licence and your intended use is not permitted by statutory regulation or exceeds the permitted use, you will need to obtain permission directly from the copyright holder. To view a copy of this licence, visit http://creativecommons.org/licenses/by/4.0/.

\section{References}

Anderson EF, McLoughlin L, Liarokapis F, Peters C, Petridis P, De Freitas $S$ (2010) Developing serious games for cultural heritage: a state-of-the-art review. Virtual Real 14(4):255-275

Aydıngün Ş, Eğilmez AH, Aydıngün H, Gürbüz İ, Gürbüz G, Albukrek M, Küçükali G, Kuruçayırlı E, Erdem B (2015) İstanbul Çatalca/ İnceğiz-Maltepe'deki Yer Altı Yapıları, Arkeoloji ve Sanat (149), pp 115-126. https://issuu.com/aspeg/docs/istanbul_catalca_inceg iz-_maltepe_d. Accessed 26 Jan 2020

Banfi F, Barazzetti L, Previtali M, Roncoroni F (2017) Historic BIM: a new repository for structural health monitoring. Int Arch Photogramm Remote Sens Spat Inf Sci XLII- 5/W1:269-274. https:// doi.org/10.5194/isprs-archives-XLII-5-W1-269-2017

Basantes J, Godoy L, Carvajal T, Castro R, Toulkeridis T, Fuertes W, Aguilar W, Tierra A, Padilla O, Mato F, Ordoez E, Addison A (2017) Capture and processing of geospatial data with laser scanner system for 3D modeling and virtual reality of amazonian caves. In: IEEE second ecuador technical chapters meeting (ETCM). pp 1-5

Buchroithner MF, Gaisecker T (2009) Terrestrial laser scanning for the visualization of a complex dome in an extreme Alpine cave system. Photogramm Fernerkund Geoinf 4:329-339

Burens A, Grussenmeyer P, Guillemin S, Carozza L, Lévêque F, Mathé V (2013) Methodological developments in 3D scanning and modelling of archaeological French heritage site: the Bronze Age painted cave of "Les Fraux", Dordogne (France). Int Arch Photogramm Remote Sens Spat Inf Sci 40(5/W2):131-135. https://doi. org/10.5194/isprsarchives-XL-5-W2-131-2013

Cosso T, Ferrando I, Orlando A (2014) Surveying and mapping a cave using $3 \mathrm{~d}$ laser scanner: the open challenge with free and open source software. Int Arch Photogramm Remote Sens Spat Inf Sci 40(5):181-186. https://doi.org/10.5194/isprsarchi ves-XL-5-181-2014

Deggim S, Kersten T, Lindstaedt M, Hinrichsen N (2017a) The return of the Siegesburg-3D-reconstruction of a disappeared and forgotten monument. Int Arch Photogramm Remote Sens Spat Inf Sci 42(2/W3):209-215. https://doi.org/10.5194/isprs-archi ves-XLII-2-W3-209-2017

Deggim S, Kersten T, Tschirschwitz F, Hinrichsen N (2017b) Segeberg 1600 - reconstructing a historic town for virtual reality visualisation as an immersive experience. Int Arch Photogramm Remote Sens Spat Inf Sci 42(2/W8):87-94. https://doi.org/10.5194/isprsarchives-XLII-2-W8-87-2017

Dirimtekin F (1957) İnceğiz Mıntıkasındaki Mağara-Manastır ve Kiliseleri, Türk Arkeoloji Dergisi, VII-2, pp 26-31. http://www. kulturvarliklari.gov.tr/sempozyum_pdf/turk_arkeoloji/07_2.turk. arkeoloji.pdf. Accessed 26 Jan 2020

Dore C, Murphy M (2017) Current state of the art historic building information modelling. Int Arch Photogramm Remote Sens Spat. Inf Sci 42(2/W5):185-192. https://doi.org/10.5194/isprs-archi ves-XLII-2-W5-185-2017

Dursun S, Sagir D, Büyüksalih G, Buhur S, Kersten T, Jacobsen K (2008) 3D city modelling of Istanbul Historic Peninsula by combination of aerial images and terrestrial laser scanning data. In: 4th EARSel Workshop on Remote Sensing for Developing Countries/ GISDECO 8, Istanbul, Turkey, June 4-7, 2008, European Association of Remote Sensing Laboratories (EARSeL), 9 p

Edler D, Husar A, Keil J, Vetter M, Dickmann F (2018) Virtual reality (VR) and open source software: a workflow for constructing 
an interactive cartographic VR environment to explore urban landscapes. Kartographische Nachrichten J Cartogr Geogr Inf 68(1):5-13

Gaitatzes A, Christopoulos D, Roussou M (2001) Reviving the past: cultural heritage meets virtual reality. In: Proceedings of the 2001 Conference on Virtual Reality, Archeology, and Cultural Heritage, Glyfada, Greece, November 28-30, 2001, pp 103-110. https://doi. org/10.1145/584993.585011

Gallay M, Kaňuk J, Hochmuth Z, Meneely JD, Hofierka J, Sedlák V (2015) Large-scale and high-resolution 3-D cave mapping by terrestrial laser scanning: a case study of the Domica Cave, Slovakia. Int J Speleol 44(3):277-291

Gonzalez-Aguilera D, Muñoz AL, Lahoz JG, Herrero JS, Corchón MS, García E (2009) Recording and modeling Paleolithic caves through laser scanning. In: Proceedings of the IEEE International Conference on Advanced Geographic Information Systems \& Web Services (GEOWS 2009), pp 19-26. https://doi.org/10.1109/ GEOWS.2009.7

Grussenmeyer P, Guillemin S (2011) Photogrammetry and laser scanning in cultural heritage documentation: an overview of projects from INSA Strasbourg. In: GTC2011 Symposium "Geomatics in the City", Jeddah, Saudi Arabia, May 2011, 8 p

Grussenmeyer P, Landes T, Alby E, Carozza L (2010) High resolution $3 \mathrm{D}$ recording and modelling of the Bronze Age cave "Les Fraux" in Périgord (France). Int Arch Photogramm Remote Sens Spat Inf Sci 38:262-267

Grussenmeyer P, Burens A, Moisan E, Guillemin S, Carozza L, Bourrillon R, Petrognani S (2012) 3D multi-scale scanning of the archaeological cave les Fraux in Dordogne (France). In: Ioannides M, Fritsch D, Leissner J, Davies R, Remondino F, Caffo R (eds) Progress in cultural heritage preservation, EuroMed 2012, Lecture Notes in Computer Science, vol 7616. Springer, Berlin, Heidelberg, pp 388-395. https://doi.org/10.1007/978-3-642-34234-9_39

Kersten T, Büyüksalih G, Baz I, Jacobsen K (2009) Documentation of Istanbul historic peninsula by kinematic terrestrial laser scanning. Photogram Rec 24(126):122-138

Kersten T, Büyüksalih G, Tschirschwitz F, Kan T, Deggim S, Kaya Y, Baskaraca AP (2017a) The Selimiye Mosque of Edirne, Turkey-an immersive and interactive virtual reality experience using HTC Vive. Int Arch Photogramm Remote Sens Spat Inf Sci 42(5/W1):403-409. https://doi.org/10.5194/isprs-archi ves-XLII-5-W1-403-201

Kersten T, Tschirschwitz F, Deggim S (2017b) Development of a virtual museum including a 4D presentation of building history in virtual reality. Int Arch Photogramm Remote Sens Spat. Inf Sci 42(2/W3):361-367. https://doi.org/10.5194/isprs-archi ves-XLII-2-W3-361-2017

Kersten Th, Tschirschwitz F, Lindstaedt M, Deggim S (2018) The historic wooden model of Solomon's Temple: 3D recording, modelling and immersive virtual reality visualisation. J Cult Herit Manag Sustain Dev Spec Issue Digit Workflows Conserv Sustain Hist Places 8(4):448-464

Lerma JL, Navarro S, Cabrelles M, Villaverde V (2010) Terrestrial laser scanning and close range photogrammetry for 3D archaeological documentation: the Upper Palaeolithic Cave of Parpalló as a case study. J Archaeol Sci 37(3):499-507

Liarokapis F, Petridis P, Andrews D, de Freitas S (2017) Multimodal serious games technologies for cultural heritage. In: Ioannides M,
Magnenat-Thalmann N, Papagiannakis G (eds) Mixed reality and gamification for cultural heritage. Springer, Berlin, pp 371-392

Lütjens M, Kersten T, Dorschel B, Tschirschwitz F (2019) Virtual reality in cartography: immersive $3 \mathrm{D}$ visualization of the Arctic Clyde Inlet (Canada) using digital elevation models and bathymetric data. MDPI Multimodal Technol Interact Spec Issue Interact 3D Cartogr 3(1):9

McCaffrey M (2017) Unreal engine VR cookbook: developing virtual reality with UE4 (game design), 1st edn. Addison-Wesley, Boston

Mohammed Oludare I, Pradhan B (2016) A decade of modern cave surveying with terrestrial laser scanning: a review of sensors, method and application development. Int J Speleol 45(1):71-88

Mortara M, Catalano CE, Bellotti F, Fiucci G, Houry-Panchetti M, Petridis P (2014) Learning cultural heritage by serious games. J Cult Herit 15(3):318-325

Nocerino E, Menna F, Farella E, Remondino F (2019) 3D virtualization of an underground semi-submerged cave system. Int Arch Photogramm Remote Sens Spat Inf Sci 42(2/W15):857-864. https://doi. org/10.5194/isprs-archives-XLII-2-W15-857-2019

Pasinli A, Gökyıldırım T, Birgili T, Düzgüner F (1994) İnceğizMaltepe Nekropolü 1992 Y1lı Kurtarma Kazısı. IV. Müze Kurtarma Kazıları Semineri, 26-29 Nisan 1993 Marmaris, Kültür Bakanlığı Yayınları, pp 339-356. http://www.kulturvarliklari. gov.tr/sempozyum_pdf/muze_kurtarma/04.muze.kurtarma.pdf. Accessed 26 Jan 2020

Pasinli A, Gökyıldırım T, Düzgüner F, Güven F (1997) Çatalca-İnceğiz Köyü Maltepe Nekropolü 1995 Yılı Kurtarma Kazısı. VII. Müze Kurtarma Kazıları Semineri, 8-10 Nisan 1996 Kuşadası, Kültür Bakanlığı Yayınları, pp 77-88. http://www.kulturvarliklari. gov.tr/sempozyum_pdf/muze_kurtarma/07.muze.kurtarma.pdf. Accessed 26 Jan 2020

Rüther H, Chazan M, Schroeder R, Neeser R, Held C, Walker SJ, Matmon A, Horwitz LK (2009) Laser scanning for conservation and research of African cultural heritage sites: the case study of Wonderwerk Cave, South Africa. J Archaeol Sci 36(9):1847-1856

Shults R, Bilous M, Kovtun V (2019) Monitoring and preservation of the Kyiv Pechersk Lavra Caves. Int Arch Photogramm Remote Sens Spat Inf Sci 42(2/W11):1053-1058

Tschirschwitz F, Büyüksalih G, Kersten T, Kan T, Enc G, Baskaraca AP (2019a) Virtualising an OTTOMAN fortress-laser scanning and 3D modelling for the development of an interactive, immersive virtual reality application. Int Arch Photogramm Remote Sens Spat Inf Sci 42(2/W9):723-729

Tschirschwitz F, Richerzhagen C, Przybilla H-J, Kersten Th (2019b) Duisburg 1566: transferring a Historic 3D city model from google earth into a virtual reality application. PFG J Photogramm Remote Sens Geoinf Sci 87(1-2):47-56

Ulusoy Binan D (2017) Tarihi ve Mimari Kültürel Miras Alanlarının Sürdürülebilir Korunması. Şehir and Toplum (9), Aralık 2017Mart 2018, ISSN: 2564-7067, pp 23-32. https://www.academia. edu/37760076/TAR\%C4\%B0H\%C4\%B0_VE_M\%C4\%B0MAR\% C4\%B0_K\%C3\%9CLT\%C3\%9CREL_M\%C4\%B0RAS_ALANL ARININ_S\%C3\%9CRD\%C3\%9CR\%C3\%9CLEB\%C4\%B0L\% C4\%B0R_KORUNMASI. Accessed 26 Jan 2020

Zlot R, Bosse M (2014) Three-dimensional mobile mapping of caves. J Cave Karst Stud 76(3):191-206 